\title{
No evidence for a role of competitive capabilities of adults in causing habitat segregation of diploid and hexaploid Senecio carniolicus (Asteracaeae)
}

\author{
Karl Hülber • Andreas Berger • Christian Gilli • \\ Markus Hofbauer • Monika Patek • \\ Gerald M. Schneeweiss
}

Received: 4 March 2011 /Revised: 1 July 2011/Accepted: 2 July 2011/Published online: 4 August 2011

(C) The Author(s) 2011. This article is published with open access at Springerlink.com

\begin{abstract}
Hexaploid individuals of Senecio carniolicus (Asteraceae) predominantly occur in dense swards while diploids prevail in open vegetation. We test whether this habitat segregation is due to differential responses to competition. Linear regression models were used to relate biomass and maximum leaf length of adults to vegetation cover within radii of $20 \mathrm{~cm}$ around target individuals. Biomass differed between ploidy levels, but was independent from vegetation cover in both cytotypes. Maximum leaf length of diploids increased with vegetation cover, but remained constant in hexaploids. This suggests that at the adult stage diploids respond to increasing competition by changes in plant architecture rather than changes in resource utilization, while hexaploids are unaffected by competition. Consequently, other factors, such as competitive interactions at earlier life stages, likely are responsible for habitat segregation of diploid and hexaploid S. carniolicus.
\end{abstract}

Keywords Polyploidy - Competition - Alpine plants . Biomass · Vegetation cover

K. Hülber $(\bowtie)$

Vienna Institute for Nature Conservation \& Analyses,

Giessergasse 6/7, 1090 Vienna, Austria

e-mail: karl.huelber@vinca.at

K. Hülber · M. Patek

Department of Conservation Biology Vegetation and Landscape

Ecology, University of Vienna, Rennweg 14,

1030 Vienna, Austria

A. Berger - C. Gilli · M. Hofbauer - G. M. Schneeweiss Department of Systematic and Evolutionary Botany,

University of Vienna, Rennweg 14, 1030 Vienna, Austria

\section{Introduction}

Polyploidisation plays an important role in the diversification of angiosperms (Hegarty and Hiscock 2008; Soltis et al. 2009) with both the allo- (Soltis and Soltis 2009) and the autopolyploid (Parisod et al. 2010) pathway being evolutionary successful. In species with more than one ploidy level, individuals of different ploidy level are often found in the same area forming contact zones (Duchoslav et al. 2010; Hülber et al. 2009; Husband and Schemske 2000; Stahlberg 2009; Trávnícek et al. 2011). Generally, such contact zones arise from secondary contact of once allopatric cytotypes (Petit et al. 1999). Growing attention is paid to various preand postzygotic reproductive isolation mechanisms responsible for maintaining cytotype coexistence (Husband and Sabara 2004; Orr and Presgraves 2000), because these may contribute to the formation of new species (Soltis et al. 2009).

In the absence of geographic isolation, an important mode of prezygotic reproductive isolation is ecological (habitat) segregation (Rieseberg and Willis 2007), which has been recognized in several cytologically complex groups including Centaurea jacea (Hardy et al. 2000), Mercurialis апnиa (Buggs and Pannell 2007), Senecio carniolicus (Hülber et al. 2009) and Achillea borealis (Ramsey 2011). There is some evidence that adaptation to novel habitats is not only due to post-polyploidization processes such as genomic evolution or reinforcement, but may already be conferred by genome multiplication per se (Ramsey 2011). Little is known, however, about the mechanisms underlying this ecological differentiation. One potential factor is competitive ability. In polyploids, it might be increased (Maceira et al. 1993) compared with their diploid relatives due to bigger cells, higher biomass and overall higher vigor as well as broader ecological ranges of polyploids (Lumaret et al. 
1987; Otto 2007; Petit and Thompson 1997), allowing polyploids to occur in denser vegetation (Hülber et al. 2009; Stahlberg 2009). However, in arctic or alpine environments the effects of ploidy level on competitive abilities have rarely been investigated (Brochman and Elven 1992) and hence are still insufficiently understood.

A good model organism for studying causes of habitat segregation among ploidy levels is Senecio carniolicus (Asteraceae). It is a herbaceous perennial endemic to the Eastern Alps and the Carpathians, where it commonly occurs in grasslands, dwarf shrub communities, rock crevices, fellfields and stable screes over siliceous bedrock from the treeline up to 3,300 $\mathrm{m}$ a.s.l. (Reisigl and Pitschmann 1958). Within the Eastern Alps, S. carniolicus comprises three main cytotypes $(2 x, 4 x, 6 x$; Suda et al. 2007; Sonnleitner et al. 2010). The most frequent cytotypes are diploids and hexaploids and they frequently co-occur in mixed populations within narrow contact zones (Sonnleitner et al. 2010; Suda et al. 2007). Previous studies found cytotypes of $S$. carniolicus segregating along an ecological gradient with diploids occurring mainly in open vegetation on rocky micro-sites, whilst the hexaploids were more abundant on sites with high vegetation cover (Hülber et al. 2009; Schönswetter et al. 2007; Sonnleitner et al. 2010). As underlying causes, different competitive abilities of cytotypes have been hypothesized (Sonnleitner et al. 2010): due to lower vigor and resulting lower competitiveness diploids would be forced into more open habitats.

Ecological segregation of morphologically differentiated cytotypes is commonly observed within polyploid complexes. However, the interpretation of higher competitive abilities of polyploids causing this segregation has rarely been investigated explicitly and evidence for alpine species is totally lacking. Thus, in the present study we examine whether the observed ecological segregation of diploid and hexaploid S. carniolicus is a result of different competitiveness. Specifically, we relate performance traits of adult plants (biomass, maximum leaf length) to vegetation cover expecting a stronger decrease in biomass and leaf length of diploids compared with that of hexploids with increasing cover.

\section{Materials and methods}

Field work and plant material

Di- and hexaploid individuals of $S$. carniolicus were randomly collected at the south-eastern slope of Mt Hoher Sadnig (Fig. 1), mountain range of Goldberggruppe, Carinthia, Austria. The collection site was located within a contact zone subject of previous studies (Hülber et al. 2009; Schönswetter et al. 2007). It is situated within the alpine

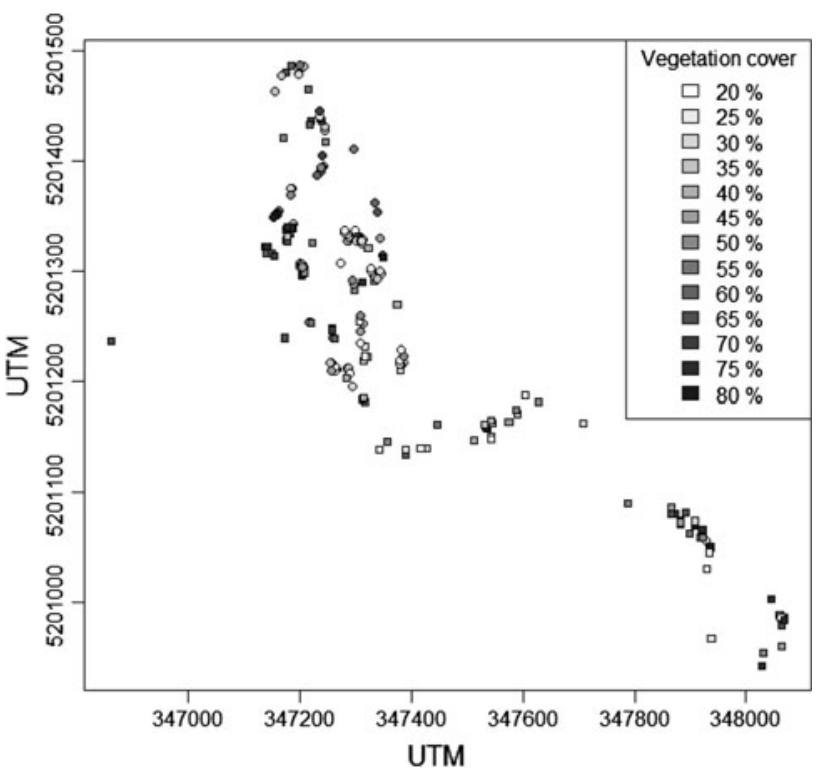

Fig. 1 Distribution of 106 diploid (circles) and 104 hexaploid (squares) individuals of Senecio carniolicus on Mt Hoher Sadnig, mountain range of Goldberggruppe, Carinthia, Austria. Gray shading represents the total cover of vascular plants within a radius of $20 \mathrm{~cm}$ around each individual

vegetation belt, which is dominated by Carex curvula grasslands and dwarf shrub communities intermixed with local open habitats (wind-exposed ridges, rocky outcrops). In total, 210 adult non flowering plants (106 diploids, 104 hexaploids) were investigated. Cytotype assignment was based on morphological characters, with hexaploids having less hairy, larger and more shallowly lobed leaves than diploids (Flatscher 2010). Only unambiguously identifiable individuals were selected. Within a radius representing the maximum horizontal spread of neighboring plants (i.e. of $20 \mathrm{~cm}$ ) around each focal individual of $S$. carniolicus, total cover of living and, if still fixed in the substrate, dead vascular plants, used as a proxy for competition, was visually estimated in terms of percentage coverage to the next $5 \%$. Bryophytes and lichens were not considered due to their low competitive ability (Löbel et al. 2006). Only sites with vegetation cover ranging from 20 to $80 \%$, that is, the range where both cytotypes were known to occur with reasonable frequencies (Hülber et al. 2009), were chosen.

Plants were collected and the following two easily assessable traits were measured: aboveground biomass, which is known to be an important response to competition (Choler et al. 2001; Chu et al. 2008; Hülber et al. 2011; Onipchenko et al. 2009), was determined at a measuring accuracy of $1 \mathrm{mg}$ after air drying at $35^{\circ} \mathrm{C}$ for several days. Although in alpine plants belowground biomass often exceeds aboveground biomass (Frank et al. 2010; Yang et al. 2009), both are generally positively correlated (Frank et al. 2010; Yang et al. 2009), and therefore the technically 
challenging quantification of belowground biomass was not undertaken. Additionally, maximum leaf length as a proxy for competition for light (Weiner 1990) was recorded in the field.

\section{Statistical analysis}

Biomass and leaf length were first log-transformed to approximate normality. Relationships between life traits and vegetation cover were assessed via linear regression models with single performance traits as response. Cytotype, vegetation cover scaled to zero mean and unit variance as well as their interaction were used as predictor terms. Analyses were conducted using R (R Development Core Team 2008).

\section{Results and discussion}

Diploid individuals of $S$. carniolicus were significantly smaller (lower biomass and shorter leaves) than polyploids (Table 1; Fig. 2), a commonly observed pattern in plants (Otto 2007). In both cytotypes, biomass was independent from neighborhood density (Table 1; Fig. 2). This disagrees with expectations because biomass has been identified as an important trait sensitive to competition also in alpine habitats (Choler et al. 2001; Hülber et al. 2011; Onipchenko et al. 2009). However, a lack of consistent differences in competitive responses between diploids and polyploids has also been found in high alpine Ranunculus adoneus using reciprocal transplantation experiments (Baack and Stanton 2005) and in lowland Aster amellus based on common garden experiments
(Münzbergova 2007). This suggests that the current distribution patterns of diploid and polyploid S. carniolicus are governed by other factors. These may include ecological differentiation in allopatry (Münzbergova 2007), rhizosphere interactions (Lamb et al. 2007) or seed limitation in diploids under high competitive pressure due to higher investment into growth rather than reproduction (Keddy 2007). Further data will be necessary to test these hypotheses.

Competition seems, however, to have a significant influence on plant architecture of diploid individuals, because the maximum leaf length increased with higher vegetation cover (Fig. 2). In contrast, leaf length of hexaploid individuals did not depend on vegetation cover. Longer leaves are assumed to be an adaptation to competition for light because in denser vegetation taller plants get a disproportionately higher share of light compared with their

Table 1 Linear regressions relating performance traits of 210 Senecio carniolicus individuals to ploidy level and vegetation cover as a proxy for the degree of competition

\begin{tabular}{lccr}
\hline & Coef $\pm \mathrm{SE}$ & $t$ value & $p$ value \\
\hline Biomass $\left(F_{3,206}=71.2 ;\right.$ & $\left.<0.001 ; R^{2}=0.51\right)$ & \\
Cytotype & $0.99 \pm 0.07$ & 87.76 & $<0.001$ \\
Vegetation cover & $0.06 \pm 0.05$ & 1.13 & 0.262 \\
Interaction & $-0.05 \pm 0.07$ & -0.63 & 0.529 \\
Leaf length $\left(F_{3,206}=134.2 ; p<0.001 ; R^{2}=0.66\right)$ & \\
Cytotype & $0.64 \pm 0.04$ & 18.21 & $<0.001$ \\
Vegetation cover & $0.11 \pm 0.03$ & 4.08 & $<0.001$ \\
Interaction & $-0.12 \pm 0.04$ & -3.31 & 0.001 \\
\hline
\end{tabular}

Performance traits were $\log$ transformed and cover was scaled prior to analysis
Fig. 2 Effects of vegetation cover on biomass and leaf length of diploid (triangles/solid lines) and hexaploid (crosses/ dashed lines) individuals of Senecio carniolicus

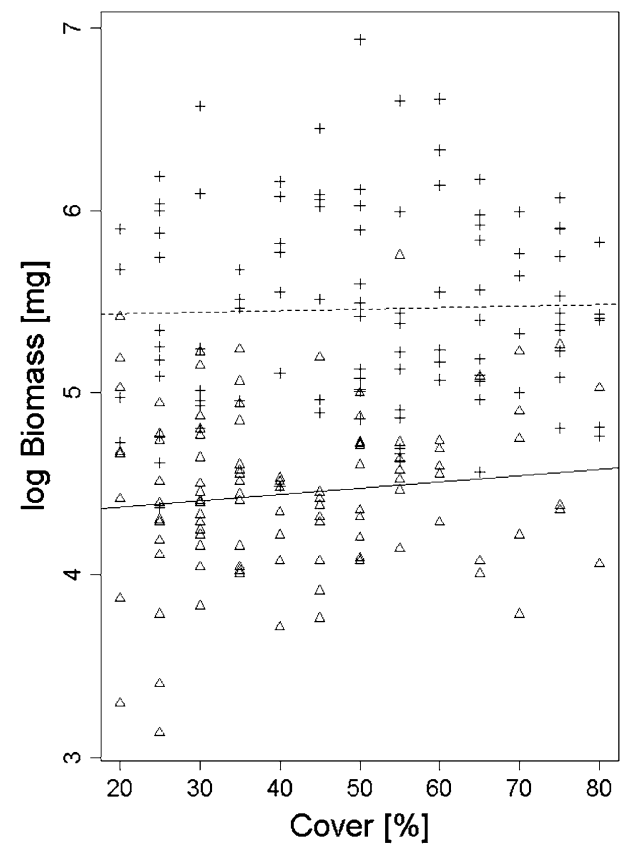


smaller neighbors (Weiner 1990). Thus, diploid S. carniolicus appears to respond to increased light competition by changed resource allocation, resulting in longer leaves, rather than reduced resource utilization.

Even if only of minor relevance for adult individuals (but see Dullinger and Hülber (2011) for counter-examples from other alpine plants), competition may well have substantial impacts on the recruitment of species. Germination, seedling growth and survival of alpine plants strongly depend on both vegetation density and snowmelt schedule (Hülber et al. 2011). In S. carniolicus, seedlings of hexaploids are bigger than those of diploids (Weis 2010) and likely have higher competitive abilities in dense vegetation due to enhanced light supply. In contrast, mechanical damages in open habitats due to wind-driven snow might be more pronounced in the bigger seedlings of polyploids. Contrary to Taraxacum venustum (Hoya et al. 2007), time to germination was shorter in diploids than in hexaploid S. carniolicus (Weis 2010) facilitating quick establishment in open habitats with low competitive pressure. Such differences in seedling establishment between cytotypes could further explain their different distribution patterns reported previously (Hülber et al. 2009).

One possible reason why biomass showed no response to competition might be increased facilitation on micro-sites with higher vegetation cover. Apart from increased competition for resources, denser vegetation may also confer facilitative effects via, for instance, higher ambient temperatures (Körner 2003) avoiding frost damages (Inouye 2008, 2000), shelter against wind (Carlsson and Callaghan 1991), reduced soil movements (Körner 2003) and diminished herbivory pressure (Schöb et al. 2010). Facilitation is of special importance in stressful alpine environments, where positive interactions of plants have been found to increase with stress (Bertness and Callaway 1994; Callaway et al. 2002; Choler et al. 2001). Consequently, the effects of competition and facilitation might counterbalance each other (Klanderud 2010; Schöb et al. 2010) resulting in a net effect of no response in biomass. Further studies, such as removal experiments, will be necessary to assess the strength of competition and facilitation in the studied vegetation zones.

In conclusion, our results provide no evidence that aboveground competition at the adult stage contributes to the observed habitat segregation between diploid and hexaploid individuals of $S$. carniolicus. However, we suppose that a combination of abiotic stressors associated with early snowmelt and effects of the changing neighborhood density influencing the reproduction (seed yield and recruitment) rather than the vegetative growth might be responsible for differences in the distribution of diploid and hexploid $S$. carniolicus. Therefore, further studies such as removal experiments or reciprocal transplantations including seeds and seedlings are necessary to identify the underlying causalities of the observed ecological segregation within the polyploid-complex of S. carniolicus.

Acknowledgments We are grateful to Michaela Sonnleitner and Ruth Flatscher for helpful discussions, and Julia Kirchstetter, Ilse Peter, Agnes Dellinger, Claudia Unger, and Lorenz Mastalir for their help in the field. This work was supported by the Austrian Science Fund (P20736-B16).

Open Access This article is distributed under the terms of the Creative Commons Attribution Noncommercial License which permits any noncommercial use, distribution, and reproduction in any medium, provided the original author(s) and source are credited.

\section{References}

Baack EJ, Stanton ML (2005) Ecological factors influencing tetraploid speciation in snow buttercups (Ranunculus adoneus): niche differentiation and tetraploid establishment. Evolution 59:19361944

Bertness MD, Callaway R (1994) Positive interactions in communities. Trends Ecol Evol 9:191-193

Brochman C, Elven R (1992) Ecological and genetic consequences of polyploidy in arctic Draba (Brassicaceae). Evol Trends Plants 6:111-124

Buggs RJA, Pannell JR (2007) Ecological differentiation and diploid superiority across a moving ploidy contact zone. Evolution 61:125-140

Callaway RM, Brooker RW, Choler P, Kikvidze Z, Lortie CJ, Michalet R, Paolini L, Pugnaire FI, Newingham B, Aschehoug ET, Armas C, Kikodze D, Cook BJ (2002) Positive interactions among alpine plants increase with stress. Nature 417:844-848

Carlsson BA, Callaghan TV (1991) Positive plant interactions in tundra vegetation and the importance of shelter. J Ecol 79:973-983

Choler P, Michalet R, Callaway RM (2001) Facilitation and competition on gradients in alpine plant communities. Ecology 82:3295-3308

Chu CJ, Maestre FT, Xiao S, Weiner J, Wang YS, Duan ZH, Wang G (2008) Balance between facilitation and resource competition determines biomass-density relationships in plant populations. Ecol Lett 11:1189-1197

Duchoslav M, Safarova L, Krahulec F (2010) Complex distribution patterns, ecology and coexistence of ploidy levels of Allium oleraceum (Alliaceae) in the Czech Republic. Ann Bot 105:719-735

Dullinger S, Hülber K (2011) Experimental evaluation of seed limitation in alpine snowbed plants. PLoS ONE 6:e21537. doi: 10.1371/journal.pone.0021537

Flatscher R (2010) Morphologische Differenzierung der sympatrischen di-, tetra- und hexaploiden Zytotypen von Senecio carniolicus s.l. (syn. Jacobaea carniolica, Asteraceae). Diploma thesis, University of Vienna

Frank DA, Pontes AW, Maine EM, Caruana J, Raina R, Raina S, Fridley JD (2010) Grassland root communities: species distributions and how they are linked to aboveground abundance. Ecology 91:3201-3209

Hardy OJ, Vanderhoeven S, De Loose M, Meerts P (2000) Ecological, morphological and allozymic differentiation between diploid and tetraploid knapweeds (Centaurea jacea) from a contact zone in the Belgian Ardennes. New Phytol 146:281-290 
Hegarty MJ, Hiscock SJ (2008) Genomic clues to the evolutionary success of polyploid plants. Curr Biol 18:R435-R444

Hoya A, Shibaike H, Morita T, Ito M (2007) Germination characteristics of native Japanese dandelion autopolyploids and their putative diploid parent species. J Plant Res 120:139-147

Hülber K, Sonnleitner M, Flatscher R, Berger A, Dobrovsky R, Niessner S, Nigl T, Schneeweiss GM, Kubesova M, Rauchova J, Suda J, Schönswetter P (2009) Ecological segregation drives fine-scale cytotype distribution of Senecio carniolicus in the Eastern Alps. Preslia 81:309-319

Hülber K, Bardy K, Dullinger S (2011) Effects of snowmelt timing and competition on the performance of alpine snowbed plants. Perspect Ecol 13:15-26

Husband BC, Sabara HA (2004) Reproductive isolation between autotetraploids and their diploid progenitors in fireweed, Chamerion angustifolium (Onagraceae). New Phytol 161:703-713

Husband BC, Schemske DW (2000) Ecological mechanisms of reproductive isolation between diploid and tetraploid Chamerion angustifolium. J Ecol 88:689-701

Inouye DW (2000) The ecological and evolutionary significance of frost in the context of climate change. Ecol Lett 3:457-463

Inouye DW (2008) Effect of climate change on phenology, frost damage and floral abundance of montane wildflowers. Ecology 89:353-362

Keddy PA (2007) Plants and vegetation-origin, Processes, Consequences. Cambridge University Press, Cambridge

Klanderud K (2010) Species recruitment in alpine plant communities: the role of species interactions and productivity. J Ecol 98: $1128-1133$

Körner C (2003) Alpine plant life, 2nd edn. Springer, Berlin/ Heidelberg/New York

Lamb EG, Shore BH, Cahill JF (2007) Water and nitrogen addition differentially impact plant competition in a native rough fescue grassland. Plant Ecol 192:21-33

Löbel S, Dengler J, Hobohm C (2006) Species richness of vascular plants, bryophytes and lichens in dry grasslands: the effects of environment, landscape structure and competition. Folia Geobot 41:377-393

Lumaret R, Guillerm JL, Delay J, Loutfi AAL, Izco J, Jay M (1987) Polyploidy and habitat differentiation in Dactylis glomerata L. from Galicia (Spain). Oecologia 73:436-446

Maceira NO, Jacquard P, Lumaret R (1993) Competition between diploid and derivative autotetraploid Dactylis glomerata $\mathrm{L}$. from Galicia: implications for the establishment of novel polyploid populations. New Phytol 124:321-328

Münzbergova Z (2007) No effect of ploidy level in plant response to competition in a common garden experiment. Biol J Linn Soc 92:211-219

Onipchenko VG, Blinnikov MS, Gerasimova MA, Volkova EV, Cornelissen JHC (2009) Experimental comparison of competition and facilitation in alpine communities varying in productivity. J Veg Sci 20:718-727

Orr HA, Presgraves DC (2000) Speciation by postzygotic isolation: forces, genes and molecules. Bioessays 22:1085-1094

Otto SP (2007) The evolutionary consequences of polyploidy. Cell 131:452-462
Parisod C, Holderegger R, Brochmann C (2010) Evolutionary consequences of autopolyploidy. New Phytol 186:5-17

Petit C, Bretagnolle F, Felber F (1999) Evolutionary consequences of diploid-polyploid hybrid zones in wild species. Trends Ecol Evol 14:306-311

Petit C, Thompson JD (1997) Variation in phenotypic response to light availability between diploid and tetraploid populations of the perennial grass Arrhenatherum elatius from open and woodland sites. J Ecol 85:657-667

R Development Core Team (2008) R: a language and environment for statistical computing. URL [http://www.R-project.org]

Ramsey J (2011) Polyploidy and ecological adaptation in wild yarrow. Proc Natl Acad Sci USA 108:7096-7101

Reisigl H, Pitschmann H (1958) Obere grenzen von flora und vegetation in der nivalstufe der zentralen Ötztaler alpen (Tirol). Vegetatio 8:93-129

Rieseberg L, Willis JH (2007) Plant speciation. Science 317:910-914

Schöb C, Kammer PM, Kikvidze Z, Choler P, von Felten S, Veit H (2010) Counterbalancing effects of competition for resources and facilitation against grazing in alpine snowbed communities. Oikos 119:1571-1580

Schönswetter P, Lachmayer M, Lettner C, Prehsler D, Rechnitzer S, Reich DS, Sonnleitner M, Wagner I, Hülber K, Schneeweiss GM, Travnicek P, Suda J (2007) Sympatric diploid and hexaploid cytotypes of Senecio carniolicus (Asteraceae) in the Eastern Alps are separated along an altitudinal gradient. J Plant Res 120:721-725

Soltis PS, Soltis DE (2009) The role of hybridization in plant speciation. Annu Rev Plant Biol 60:561-588

Soltis DE, Albert VA, Leebens-Mack J, Bell CD, Paterson AH, Zheng CF, Sankoff D, DePamphilisWall CW, Soltis PS PK (2009) Polyploidy and angiosperm diversification. Am J Bot 96:336-348

Sonnleitner M, Flatscher R, Garcia PE, Rauchova J, Suda J, Schneeweiss GM, Hülber K, Schönswetter P (2010) Distribution and habitat segregation on different spatial scales among diploid, tetraploid and hexaploid cytotypes of Senecio carniolicus (Asteraceae) in the Eastern Alps. Ann Bot 106:967-977

Stahlberg D (2009) Habitat differentiation, hybridization and gene flow patterns in mixed populations of diploid and autotetraploid Dactylorhiza maculata s.l. (Orchidaceae). Evol Ecol 23:295-328

Suda J, Weiss-Schneeweiss H, Tribsch A, Schneeweiss GM, Travnicek P, Schönswetter P (2007) Complex distribution patterns of di-, tetra-, and hexaploid cytotypes in the european high mountain plant Senecio carniolicus (Asteraceae). Am J Bot 94:1391-1401

Trávníček P, Dočkalová Z, Rosenbaumová R, Kubátová B, Szeląg Z, Chrtek J (2011) Bridging global and microregional scales: ploidy distribution in Pilosella echioides (Asteraceae) in central Europe. Ann Bot 107:443-454

Weiner J (1990) Asymmetric competition in plant populations. Trends Ecol Evol 11:360-364

Weis B (2010) Postzygotic isolation in the polyploid complex of a high mountain plant (Senecio carniolicus, Asteraceae). Diploma thesis, University of Vienna

Yang YH, Fang JY, Ji CJ, Han WX (2009) Above- and belowground biomass allocation in Tibetan grasslands. J Veg Sci 20:177-184 